http://ejournal.upi.edu/index.php/jaz - e-mail: jurnal.zonasi@gmail.com dan jurnal zonasi@upi.edu doi.org/10.17509/jaz.v3i2.25000

\title{
KAJIAN KONSEP ARSITEKTUR BERKELANJUTAN PADA BANGUNAN PUSAT PERBELANJAAN : MAL CILANDAK TOWN SQUARE
}

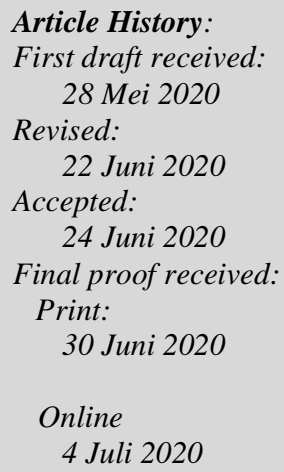

\author{
Pandu Afdhalul Mu'min ${ }^{1}$ \\ Anggana Fitri Satwikasari ${ }^{2}$ \\ 1,2 Universitas Muhammadiyah Jakarta, Jakarta, Indonesia \\ Jl. Cempaka Putih Tengah 27, RT.11/RW.5, Cemp. Putih Tim., Kec. Cemp. Putih, Kota \\ Jakarta Pusat, Daerah Khusus Ibukota Jakarta 10510. \\ Email: panduafdhalul@gmail.com \\ anggana.fitri@ftumj.ac.id
}

\begin{abstract}
New shopping center facilities in urban areas are competing to be established by managers and investors to benefit from increasing demand for people's daily needs today. However, the aspects that are applied to the building have not fully paid attention to sustainaible architecture factors, so that instead it has a negative impact on the surrounding environtment. Mall building was chosen because it is one of the examples of shopping facilities that are in demand by the community with quite rapid growth in every city, including the city of Jakarta as predicate metropolitan city and the capita of countryl today. The method used in this research is to use qualitative methods by collecting data, searching for literature, conducting observations in the field and analyzing sustainable architectural principles that have been applied to case studies. This research is expected to increase knowledge related to shopping center building standards and the application of sustainable architectural concepts that are appropriate threre in.
\end{abstract}

Keywords: Sustainaible architecture, shopping center, qualitative method.

Abstrak: Fasilitas pusat perbelanjaan baru di wilayah perkotaan berlomba - lomba didirikan oleh para pengelola dan investor untuk meraup keuntungan dari meningkatnya permintaan kebutuhan harian masyarakat nya saat ini. Akan tetapi, aspek - aspek yang diterapkan pada bangunan belum sepenuhnya memperhatikan faktor arsitektur berkelanjutan, sehingga malah menimbulkan dampak negatif pada lingkungan sekitarnya. Bangunan mal dipilih karena merupakan salah satu contoh fasilitas pusat perbelanjaan yang diminati oleh masyarakat dengan pertumbuhan yang cukup pesat di setiap kota, tak terkecuali kota Jakarta sebagai penyandang predikat kota metropolitan dan ibukota negara saat ini. Adapun dalam penelitian ini metode yang digunakan menggunakan metode kualitatif dengan melakukan pengumpulan data, mencari literatur, melakukan obvservasi ke lapangan dan menganalisis prinsip arsitektur berkelanjutan yang sudah diterapkan pada studi kasus. Dengan dilakukan nya penelitian ini diharapkan dapat meningkatkan pengetahuan terkait standar bangunan pusat perbelanjaan serta penerapan konsep arsitektur berkelanjutan yang sesuai didalamnya.

Kata Kunci: Arsitektur berkelanjutan, pusat perbelanjaan, metode kualitatif.

\section{Pendahuluan}

Pentingnya konsep berkelanjutan meningkat setiap hari, hal ini didasari oleh berbanding lurusnya peningkatan jumlah populasi manusia dari waktu ke waktu dan menurun nya sumber daya alam yang ada (Gissen, 2003). Selaras dengan hal ini, para pengelola dan investor berlomba - lomba mendirikan bangunan dan fasilitas pusat perbelanjaan baru di seluruh wilayah perkotaan di era industri seperti sekarang ini, termasuk juga di wilayah ibu kota DKI Jakarta. Akibat percepatan pembangunan dan profit yang selalu di utamakan oleh para pengelola dan investor, tak ayal menimbulkan dampak negatif berupa polusi pemanasan global dan 
kerusakan lingkungan yang di akibatkan oleh berdirinya sebuah bangunan, hal ini dapat didasari akibat penggunaan material tidak ramah lingkungan, minimnya area penghijauan di sekitar tapak sampai pemilihan lahan yang tidak sesuai prosedur. Kita tentu dirugikan oleh dampak yang ditimbulkan akibat langkah yang tidak sesuai oleh pengelola dan investor dalam mendirikan bangunan, misalnya pada area yang seharusnya merupakan area resapan, diganti dengan beton dan perkerasan lain nya.

Misalnya masalah banjir yang tak kunjung terselesaikan di Jakarta, masalah ini terjadi semakin parah dan bukan semakin membaik, akibat tidak adanya kesadaran dari masyarakat dan pihak-pihak terkait untuk selalu menjaga lingkungan sekitar. Percepatan pertumbuhan pembangunan yang tidak diiringi dengan peningkatan kualitas SDM yang baik, semakin meperburuk keadaan saat ini. Cerminan wajah ibukota saat ini dapat dilihat dari kumuhnya lingkungan di sudut kota dan kemcatan yang terjadi dimana - mana.

Menurut data dari Badan Pusat Statistik (BPS), DKI Jakarta memiliki total 80 pusat perbelanjaan yang tersebar di seluruh penjuru kota, namun hanya segelintir yang tergolong kedalam kategori berkelanjutan. Oleh sebab itu, seiring dengan upaya percepatan pertumbuhan ekonomi dan pembangunan, tentunya perlu diimbangi dengan peningkatan kualitas SDM yang baik serta rasa tanggung jawab yang tinggi untuk dapat menjaga dan peduli terhadap lingkungan sekitar dengan tidak merusaknya.

\section{Tujuan}

Adapun tujuan dari penelitian ini adalah :

1. Mengetahui konsep arsitektur berkelanjutan.

2. Memahami penerapan konsep arsitektur berkelanjutan pada bangunan pusat perbelanjaan Mal Cilandak Town Square.

\subsection{Konsep Arsitektur Berkelanjutan}

Sebuah konsep arsitektur dapat dikatakan sebagai arsitektur yang berkelanjutan apabila dari konsep arsitektur tersebut dapat memenuhi kebutuhan pengguna nya pada masa sekarang, tanpa membahayakan kemampuan generasi masa yang akan datang untuk memenuhi kebutuhan hidupnya (Steele, 1997).

\section{Prinsip Arsitektur Berkelanjutan}

Menurut Ardiani Y Mila dalam bukunya yang berjudul arsitektur berkelanjutan tahun 2005 terdapat beberapa prinsip arsitektur yang berkelanjutan yaitu :

1. Ekologi perkotaan. Sebuah konsep arsitektur berkelanjutan memiliki peranan penting dalam mewujudkan iklim perkotaan yang baik dari segi lingkungan dan kehidupan disekitarnya.

2. Strategi energi. Sebuah konsep arsitektur berkelanjutan semestinya dapat mengurangi penggunaan energi fosil dan beralih dengan menggunakan energi alami yang dapat diperbaharui seperti cahaya matahari, angin, dan lain sebagainya.

3. Pengelolaan air. Sebuah konsep arsitektur berkelanjutan semestinya dapat mengoptimalkan penggunaan air bersih dan mengurangi dampak negatif dari air bekas pakai dari fasilitas bangunan terhadap lingkungan sekitarnya.

4. Pengelolaan limbah.Pada dasarnya sampah dapat dibagi kedalam 3 kategori yaitu, sampah cair, sampah padat dan gas.Pada karya arsitektur yang berkelanjutan, ketiga kategori sampah ini dapat dikurangi ataupun dimanfaatkan atau hanya sekedar aman bagi lingkungan sekitarnya.

5. Material dipilih. Dalam pemilihan material pada bangunan perlu memperhatikan unsur keamanan dan kenyamanan penghuni, tidak lupa juga memperhatikan lokasi penyedia material guna memperhatikan efisiensi biaya pengiriman dan waktu pengiriman.

6. Komunitas lingkungan. Komunitas lingkungan yang dimaksud ialah kegiatan penghuni bangunan selain menghuni bangunan, seperti penggalaan budaya menanam, mengolah sumber daya alam sekitar menjadi produk khas lokal, pengelolaan sampah bekas pakai dan lain sebagainya.

7. Strategi ekonomi. Strategi ekonomi disini maksudnya ialah keikutsertaan dari pihak-pihak terkait untuk memberdayakan Usaha Kecil Menengah (UKM) maupun usaha berbasis komunitas di kawasan tersebut.

8. Pelestarian atau penciptaan budaya. Budaya sangat erat kaitan nya dengan karakter dan identitas dari sebuah kawasan, adapun beberapa contoh budaya yang dapat dikembangkan dapat berupa adat istiadat, makanan tradisional, dan sebagainya. 


\subsection{Organisasi Bangunan Hijau ( Berkelanjutan )}

Adapun organisasi green building di Indonesia bernama Green Building Council Indonesia atau biasa disingkat GBCI. GBCI ialah lembaga independen yang berkomitmen terhadap pendidikan masyarakat dalam mengaplikasikan praktik-praktik lingkungan dan memfasilitasi transformasi industri bangunan yang berkelanjutan. GBCI memiliki tujuan untuk melakukan transformasi dan diseminasi kepada masyarakat dan pelaku bangunan untuk menerapkan prinsip-prinsip bangunan hijau, khususnya di sektor industri bangunan gedung di Indonesia.

Adapun selain menggunakan prinsip arsitektur berkelanjutan sebagai tolok ukur, terdapat pula perangkat tolok ukur bangunan hijau GBCI untuk mempermudah penilaian dan analisis pada studi kasus. GBCI mengeluarkan sistem rating yang dinamakan GREENSHIP. Adapun garis besar GREENSHIP rating tools GBCI berisi :

1. Pengembangan site yang sesuai. Didalam nya terdapat sub penilaian seperti kemudahan akses sekitar, pengurangan kendaraan bermotor, pengolahan tanaman dalam site.

2. Efisiensi energi dan pemeliharaan. Didalam nya terdapat sub penilaian seperti kinerja penggunaan energi yang minim, pengawasan dan pengendalian energi, operasi dan pemeliharaan, energi terbarukan dalam site.

3. Konservasi air. Didalamnya terdapat sub penilaian seperti manajemen penggunaan air, pengawasan dan pengendalian penggunaan air, kualitas air, air daur ulang.

4. Siklus dan penggunaan sumber daya material. Didalamnya terdapat sub penilaian seperti kebijakan pembelian bahan material, manajemen bahan tak terpakai, Pengelolaan limbah berbahaya.

5. Kesehatan dan kenyamanan ruang dalam. Didalamnya terdapat sub penilaian seperti upaya melarang merokok, pemaksimalan penggunaan udara alami, pengawasan dan pengendalian emisi $\mathrm{CO} 2$ dan $\mathrm{CO}$, Kenyamanan termal.

6. Manajemen lingkungan bangunan. Didalamnya terdapat sub penilaian seperti kebijakan operasi dan pemeliharaan, inovasi, Pelatihan operasi dan pemeliharaan.

\subsection{Standar Desain Terkait Pola Massa Bangunan dan Rencana Tapak Terhadap Lingkungan}

Dalam merencanakan dan merancang sebuah bangunan, tentunya terdapat beberapa aspek yang dapat digunakan sebagai acuan desain arsitektur berkelanjutan, adapun penjabaran nya sebagai berikut :

a. Bentuk massa bangunan

Bentuk massa bangunan bisa merupakan penggambaran dari lingkungan bangunan tersebut berada, misalnya terdapat sebuah bangunan yang berada di tepi pantai dengan gelombang ombak dan pantai yang indah serta tanaman yang menghiasi area itu. Bentuk massa bangunan akan terlihat sangat indah, apabila menyerap elemen - elemen sekitar mulai dari gerakan ombak, garis pantai, sampai desiran angin yang berhrmbus, guna mencapai keharmonisan antara lingkungan binaan dengan lingkungan alam (Idedhyana, 2016)

b. Orientasi bangunan terhadap matahari

Penyerapan cahaya matahari dalam desain bangunan dapat diketahui melalui pergerakan matahari dari terbit sampai tenggelam, menggunakan sun path diagram. Diagram ini berupa suatu lingkaran dengan titik penyelidikan berada di tengah sebagai pusat. Garis keliling adalah horison, dua koordinat penentunya adalah Azimuth dan Altitude (gambar 2). Dengan mengetahui jalur pergerakan matahari kita dapat menentukan letak bukaan dan bagian bangunan yang terkena matahari langsung. 


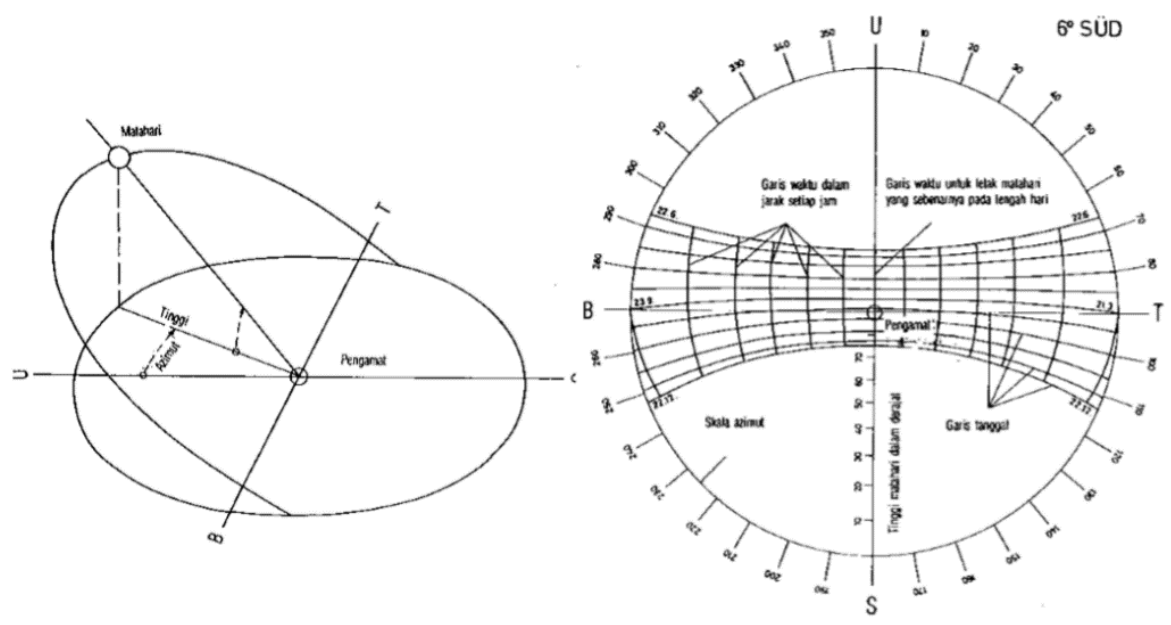

Gambar 1 Jalur pergerakan matahari

Sumber : Lippsmier, 1994, diakses 2020

\section{c. Kearifan lokal}

Setiap wilayah tentunya memiliki ciri khas khusus yang berbeda dengan wilayah lain, tapak dan bangunan yang berdiri di sebuah wilayah akan memiliki nilai tersendiri jika mampu merepresentasikan kearifan lokal di wilayah tersebut kedalam site dan bangunan (Idedhyana, 2016)

\subsection{Pusat Perbelanjaan}

Bangunan perbelanjaan ialah kumpulan toko ritel dan fasilitas terkait yang direncanakan sebagai sebuah kesatuan untuk memberikan kenyamanan belanja maksimal kepada pelanggan dan eksposur maksimum ke barang dagangan (Chiara \& callender, 1973). Pusat perbelanjaan dewasa ini lebih dari sekedar tempat berbelanja untuk mememnuhi kebutuhan, melainkan juga bertranformasi sebagai ruang pertemuan sosial bagi banyak orang. Sebagian masyarakat menghabiskan waktu luang mereka dan bersosialisasi di ruang publik pusat perbelanjaan hal itu mendorong ruang publik di pusat perbelanjaan merangkap menjadi area rekreasi.

Ruang publik di pusat perbelanjaan sebagai area rekreasi harus dipertimbangkan kembali dalam arti peningkatan kualitas ruang bagi mereka dan juga kepedulian berkelanjutan dalam desain interior bangunan pusat perbelanjaan (Aktas, 2012). Pusat perbelanjaan kontemporer juga harus mengikuti kriteria desain sebagai berikut (Gissen, 2003):

1. Hindari pembatasan dengan alam untuk mencapai ruang dalam yang memberikan manfaat positif bagi penghuninya. Bangunan harus dirancang untuk memaksimalkan cahaya alami di siang hari dibanding cahaya buatan, demikian juga bangunan harus berorientasi pada penghawaan alami dengan memanfaatkan udara segar daripada dikendalikan melalui sistem penghawaan yang menggunakan energi buatan.

2. Mudah dalam pengumpulan dan menyimpan sumber energi yang diterima, khususnya energi matahari, dan kemudian dapat dimanfaatkan bila diperlukan. Bangunan juga harus dirancang agar dapat mengkonsumsi energi buatan seminim mungkin.

3. Menghormati lingkungan sekitar. Mereka tidak hanya meminimalisir konsumsi energi buatan namun mereka juga harus bertujuan untuk tidak menimbulkan dampak lingkungan yang negatif. Siklus energi lokal dapat dimanfaatkan, tetapi tidak boleh diubah atau digunakan dengan cara yang tidak berkelanjutan.

Desain interior sebuah pusat perbelanjaan dapat berpengaruh pada konsep keberlanjutan bangunan. Area publik, tempat aktivitas sosial dan rekreasi serta sirkulasi di pusat perbelanjaan dapat memberikan kontribusi besar bagi keberlanjutan pada pusat perbelanjaan. (Gissen, 2003)

\section{Metode Penelitian}

Dalam metode penelitian jurnal ini, penulis menggunakan jenis penelitian deskriptif kualitatif dengan melakukan penggambaran terkait penjabaran data studi kasus yang digunakan dengan aplikasi nya terhadap konsep arsitektur berkelanjutan yang telah diterapkan. Adapun tahapan nya ialah :

1. Penentuan jenis penelitian. Hal ini dilakukan untuk menentukan proses pengambilan data dilapangan. Didapatkan penulis menggunakan metode deskriptif kualitatif dalam penyajian data.

2. Penentuan studi kasus. Banyak sekali pusat perbelanjaan dalam sebuah kota, dalam hal ini peneliti memilah objek penelitian yang sudah mengarah ke penerapan arsitektur berkelanjutan. Adapun objek penelitian yang didapatkan ialah Mal Cilandak Town Square. 
3. Pengumpulan data. Pengumpulan data diperoleh melalui observasi langsung di lapangan dengan studi literatur untuk mendukung pembahasan penelitian yaitu : Gambaran umum arsitektur berkelanjutan dan prinsip - prinsip arsitektur berkjelanjutan

4. Analisis data. Melakukan proses penjabaran data yang diperoleh dan analisis terkait prinsip arsitektur berkelanjutan yang sudah diterapkan pada objek penelitian menggunakan parameter penilaian dari prinsip arsitektur berkelanjutan dan GBCI (Green Building Council Indonesia).

\section{Hasil dan Pembahasan}

Berikut ialah hasil dan pembahasan inti dari penelitian ini yang berisi data fisik kondisi eksisting serta analisis penilaian konsep arsitektur berkelanjutan yang diterapkan pada bangunan dan tapak Mal Cilandak Town Square.

\section{a. Analisis seputar lahan}

Sebuah lahan dapat dikategorikan memenuhi kriteria berkelanjutan apabila memenuhi aspek kemudahan akses pengunjung, memiliki upaya pelestarian dan penghjauan, memiliki pengelolaan tanaman yang baik dan meminimalisir dampak negatif yang dapat ditimbulkan terhadap lingkungan sekitar :

\begin{tabular}{|c|c|c|}
\hline No. & Analisis prinsip seputar lahan & Mal Cilandak Town Square \\
\hline 1 & Kemudahan akses pengunjung & $\begin{array}{l}\text { Mal CITOS berada tepat di pinggir jalan raya TB } \\
\text { Simatupang, dapat diakses dengan mudah baik itu } \\
\text { menggunakan kendaraan umum ataupun } \\
\text { menggunakan kendaraan pribadi. Akses kedalam } \\
\text { bangunan terletak } \pm 12 \text { meter dari jalan raya TB } \\
\text { Simatupang. }\end{array}$ \\
\hline 2 & $\begin{array}{l}\text { Upaya pelestarian dan } \\
\text { penghijauan }\end{array}$ & $\begin{array}{l}\text { Terdapat area hijau di sekitar tapak seperti yang dapat } \\
\text { dilihat pada gambar diatas. Sebagian besar jalur } \\
\text { sirkulasi kendaraan bermotor menggunakan konblok } \\
\text { yang memungkinkan air dapat terserap melalui celah } \\
\text { kedalam tanah. Perlu adanya penambahan area hijau } \\
\text { guna meningkatkan kenyamanan pengunjung mal }\end{array}$ \\
\hline 3 & Pengelolaan tanaman & $\begin{array}{l}\text { Terdapat beberapa jenis tanaman yang tumbuh di } \\
\text { sekitar area bangunan, mulai dari tanaman hias, } \\
\text { sampai tanaman penyejuk yang berfungsi } \\
\text { meningkatkan kadar oksigen pada siang hari dan } \\
\text { menyaring kebisingan dari luar, seperti tanaman } \\
\text { palem, tanaman paku, dan lain nya. }\end{array}$ \\
\hline
\end{tabular}

Sumber: Analisis pribadi, 2020

Dalam hal pencapaian mal CITOS memiliki keunggulan, yakni kemudahan akses yang dapat dilalui pengunjung menuju mal ini baik itu dengan menggunakan moda transportasi umum ataupun pribadi. Dalam hal upaya pelestarian dan penghijauan lingkungan terdapat beberapa elemen dasar yang sudah diterapkan, 
seperti adanya tanaman untuk penghijauan dan penggunaan material paving blok pada jalur sirkulasi kendaraan bermotor, akan tetapi area perkerasan yang ada lebih dominan dibanding dengan area penghijauan oleh sebab itu dirasa perlu adanya penambahan area hijau guna meningkatkan kenyamanan pengunjung.

\section{b. Analisis efisiensi dan strategi energi}

Konsep arsitektur berkelanjutan yang baik semestinya bijak dalam penggunaan energi, mengurangi penggunaan energi fosil dan menggantinya dengan penggunaan energi alam yang dapat terbarukan seperti cahaya matahari, angin, dan lain sebagainya. Penggunaan void dapat membantu menambah efisiensi, dimana bisa menjadi alternatif desain pasif yang efektif untuk permukiman padat di daerah perkotaan, karena ventilasi vertikal membantu penghuni gedung mendapatkan lebih banyak ventilasi dan pencahayaan alami (Anggana Fitri Satwikasari, 2018). Adapun beberapa faktor yang semestinya di upayakan adalah upaya dalam penggunaan energi terbarukan, upaya meminimalisir energi buatan dan upaya meminimalisir emisi buangan :

Tabel 2 Analisis efisiensi dan strategi energi

\begin{tabular}{|c|c|c|}
\hline No & $\begin{array}{l}\text { Analisis prinsip efisiensi } \\
\text { dan strategi energi }\end{array}$ & Mal Cilandak Town Square \\
\hline 1 & $\begin{array}{l}\text { upaya dalam penggunaan energi } \\
\text { terbarukan dan meminimalisir } \\
\text { energi buatan }\end{array}$ & $\begin{array}{l}\text { Terdapat beberapa upaya meminimalisir } \\
\text { penggunaan energi buatan dan } \\
\text { memamaksimalkan penggunaan energi alami } \\
\text { pada mal ini. Seperti terdapat skylight pada } \\
\text { selasar utama bangunan yang berfungsi untuk } \\
\text { memasukan pencahayaan alami kedalam } \\
\text { bangunan di siang hari. Pada bagian atrium } \\
\text { utama, terbuka langsung menghadap keluar hal } \\
\text { ini dapat berguna untuk memasukan penghawaan } \\
\text { alami kedalam bangunan. }\end{array}$ \\
\hline 2 & $\begin{array}{l}\text { Upaya meminimalisir emisi } \\
\text { buangan }\end{array}$ & $\begin{array}{l}\text { Terdapat beberapa jenis tanaman yang } \\
\text { mengelilingi area tapak mal CITOS, hal ini dapat } \\
\text { berguna untuk meminimalisir dampak negatif } \\
\text { yang ditimbulkan oleh aktifitas di dalam dan } \\
\text { sekitar bangunan ke lingkungan sekitar, serta } \\
\text { dapat dapat berguna untuk meredam polusi } \\
\text { kendaraan bermotor dari luar ke dalam bangunan }\end{array}$ \\
\hline
\end{tabular}

Sumber : Analisis pribadi, 2020

Dalam hal penggunaan energi terbarukan dan meminimalisir energi buatan mal CITOS sudah melakukan upaya, salah satunya ialah dengan adanya penggunaan skylight dan keterbukaan pada area atrium utama guna memaksimalkan pencahayaan dan penghawaan alami masuk kedalam bangunan. Dalam hal upaya meminimalisir emisi buangan, mal ini telah melakukan upaya salah satunya dengan meletakkan vegetasi di sekitar garis terluar tapak.

\section{c. Analisis pengelolaan limbah}


Sudah semestinya limbah hasil pakai dari aktifitas pengunjung mal tidak membahayakan dan merusak lingkungan sekitar, perlu adanya kesadaran dari pengelola dan manajemen untuk menyediakan fasilitas pendukung untuk mensiasati hal tersebut. Adapun beberapa faktor yang perlu diperhatikan adalah, upaya pemisahan limbah daur ulang dan limbah berbahaya serta upaya penggunaan kemasan ramah lingkungan :

Tabel 3 Analisis pengelolaan limbah

\begin{tabular}{|c|c|c|}
\hline No & $\begin{array}{l}\text { Analisis prinsip pengelolaan } \\
\text { limbah }\end{array}$ & Mal Cilandak Town Square \\
\hline 1 & $\begin{array}{l}\text { Upaya pemisahan limbah daur } \\
\text { ulang dan limbah berbahaya }\end{array}$ & $\begin{array}{l}\text { Terdapat tempat sampah tanpa pemisahan kategori } \\
\text { (daur ulang atau non daur ulang) yang terletak di } \\
\text { setiap sudut bangunan mal CITOS. }\end{array}$ \\
\hline 2 & $\begin{array}{l}\text { Upaya penggunaan kemasan ramah } \\
\text { lingkungan }\end{array}$ & $\begin{array}{l}\text { Beberapa toko sudah menjual dagangan nya } \\
\text { menggunakan kemasan ramah lingkungan } \\
\text { berbahan dasar kertas, seperti pada gambar diatas. }\end{array}$ \\
\hline
\end{tabular}

Sumber: Analisis pribadi, 2020

Pada mal ini hanya terdapat tempat sampah biasa tanpa pemisahan sampah organik dan non organik yang terletak disetiap sudut bangunan. Dalam hal upaya penggunaan kemasan ramah lingkungan beberapa tenant di mal ini sudah mengaplikasikan kemasan ramah lingkungan.

\section{d. Analisis material}

Material merupakan salah satu faktor penting untuk tercapainya prinsip berkelanjutan, dimana material berfungsi sebagai bahan dasar berdirinya sebuah bangunan. Adapun beberapa prinsip yang perlu diperhatikan untuk memenuhi faktor material yang berkelanjutan ialah upaya penggunaan material ramah lingkungan, upaya penggunaan material daur ulang, serta upaya meminimalisir material berbahaya atau beracun :

\begin{tabular}{|l|c|c|}
\hline No & Analisis prinsip material & Tabel 4 Analisis material \\
\hline 1 & $\begin{array}{l}\text { Upaya penggunaan material } \\
\text { ramah lingkungan dan daur } \\
\text { ulang }\end{array}$ & $\begin{array}{l}\text { Material yang dominan pada bangunan ini terdiri dari } \\
\text { pasangan bata dengan finishing cat, baja dan kaca. } \\
\text { Terdapat pula material fiber glass yang digunakan } \\
\text { pada bagian skylight pada selasar utama. }\end{array}$ \\
\hline
\end{tabular}




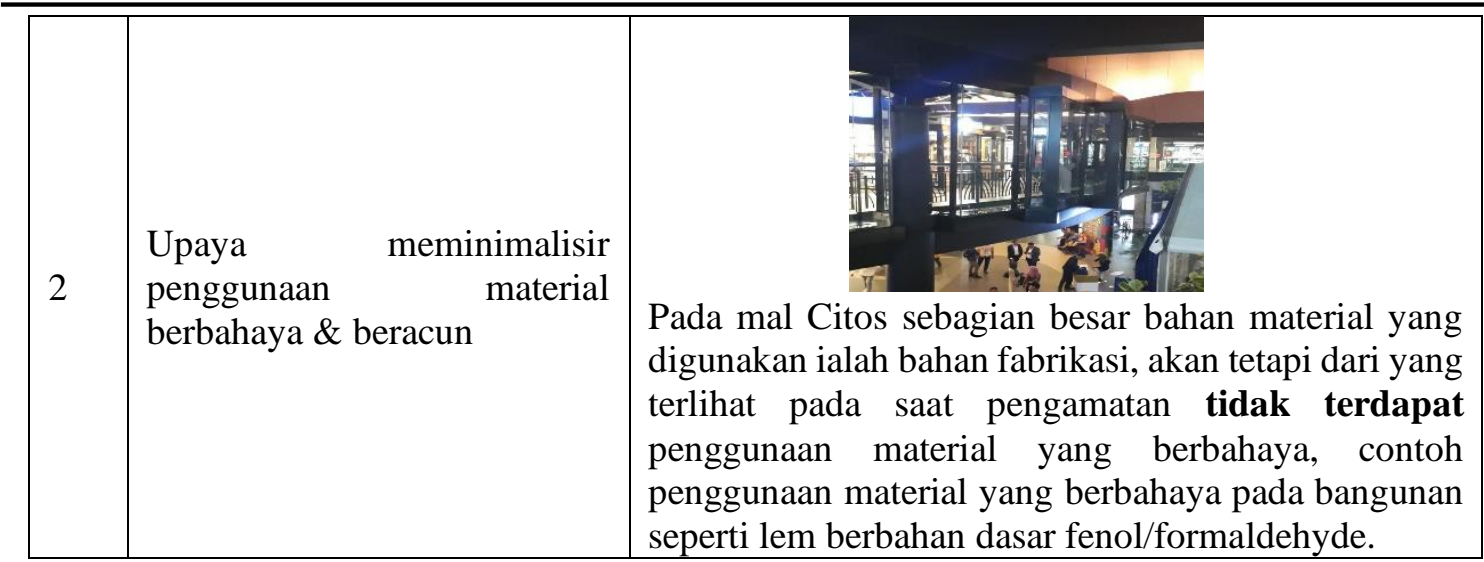

(Sumber: Analisis pribadi, 2020)

Dalam hal upaya penggunaan material ramah lingkungan dan daur ulang, mal ini sudah berupaya menerapkan dengan penggunaan material fiber di beberapa bagian nya, akan tetapi terlihat belum adanya upaya menerapkan material daur ulang pada bangunan karena dari pengamatan yang telah dilakukan, sebagian besar material yang digunakan ialah material fabrikasi dan baru. Dalam hal upaya meminimalisir penggunaan material berbahaya dan beracun mal CITOS sudah berupaya menerapkan, karena dari pengamatan yang telah dilakukan tidak terlihat adanya indikasi penggunaan material berbahaya dan beracun.

\section{e. Analisis Kenyamanan Ruang Dalam}

Kondisi ruang dalam yang sesuai merupakan salah satu faktor penting penunjang kenyamanan pengunjung pada sebuah bangunan. Adapun beberapa prinsip yang dapat mendukung tercapai kondisi ruang dalam yang nyaman ialah adanya upaya himbauan dilarang merokok, upaya ketersediaan udara segar, dan adanya upaya optimalisasi pencahayaan alami.

Tabel 5 Analisis kenyamanan ruang dalam

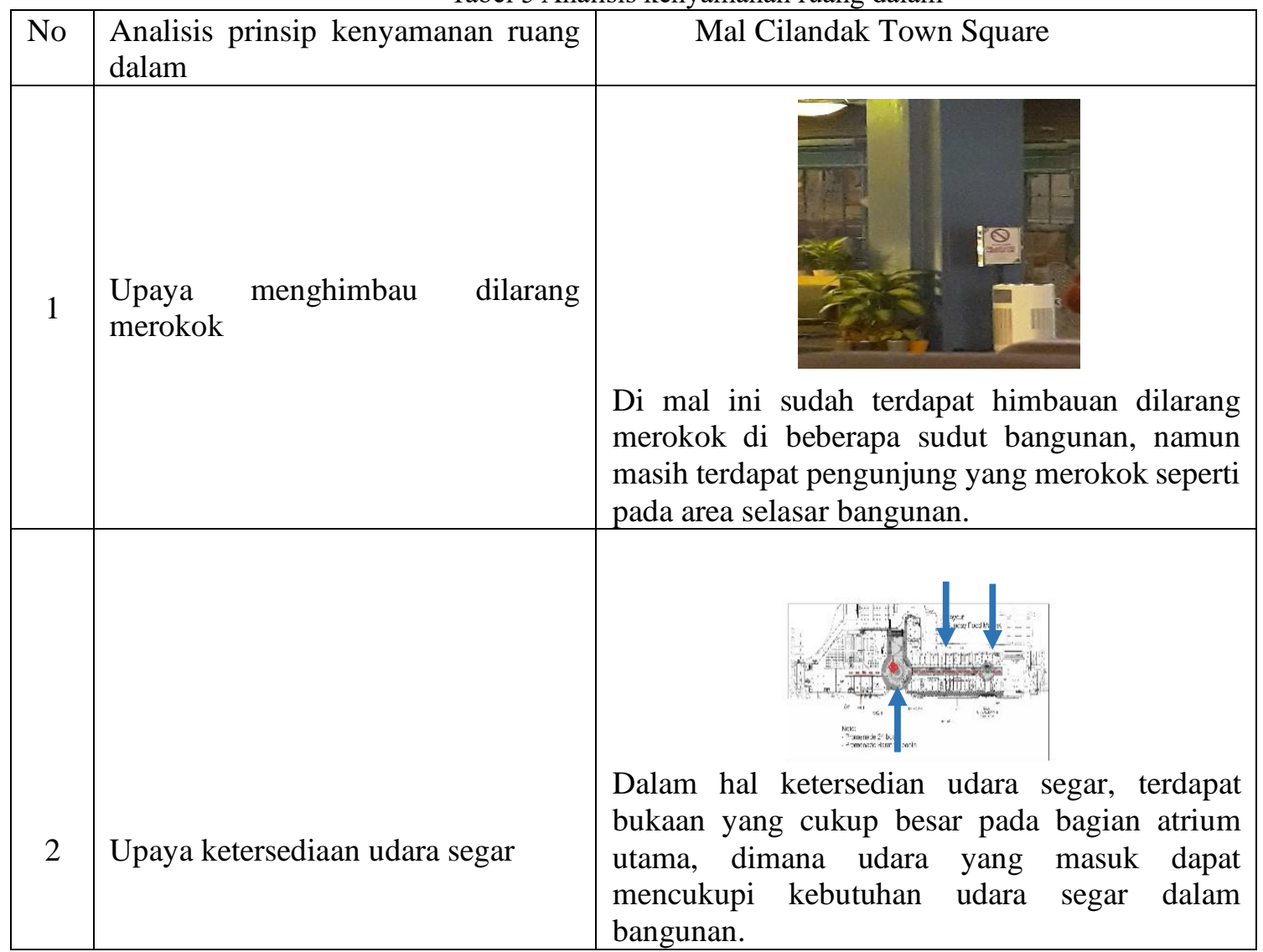




\begin{tabular}{|c|l|l|l|}
\hline 3 & $\begin{array}{l}\text { Upaya optimalisasi pencahayaan } \\
\text { alami }\end{array}$ & $\begin{array}{l}\text { Seperti yang sudah dijelaskan sebelumnya, } \\
\text { terdapat bukaan pada area selasar utama yang } \\
\text { sangat berguna untuk memasukan sinar matahari } \\
\text { pada pagi sampai sore hari guna mencukupi } \\
\text { kebutuhan cahaya di dalam bangunan. }\end{array}$ \\
\hline
\end{tabular}

Sumber : Analisis pribadi, 2020

Dalam hal upaya menghimbau dilarang merokok, mal ini sudah melakukan upaya dengan memberikan papan tulisan dilarang merokok. Mal CITOS sudah menerapkan prinsip keterdediaan cahaya alami dan udara segar untuk memenuhi kebutuhan ruang dalam.

\section{f. Analisis pengelolaan air}

Sebuah karya dari konsep arsitektur berkelanjutan semestinya dapat mengoptimalkan penggunaan air bersih dan mengurangi dampak negatif dari air bekas pakai dari fasilitas bangunan terhadap lingkungan sekitarnya. Adapun beberapa poin yang perlu diperhatikan untuk memenuhi karakteristik diatas ialah kualitas sumber air yang baik dan adanya upaya penghematan air bersih baru.

Tabel 6 Analisis pengelolaan air

\begin{tabular}{|c|l|l|}
\hline No & Analisis pengelolaan air & \multicolumn{1}{|c|}{ Mal Cilandak Town Square } \\
\hline 1 & $\begin{array}{l}\text { Kualitas sumber air yang } \\
\text { baik }\end{array}$ & $\begin{array}{l}\text { Air yang digunakan pada mal ini untuk memenuhi } \\
\text { kebutuhan pengunjung di toilet dan wastafel masing - } \\
\text { masing tenant juga terbilang bersih dan tidak berbau } \\
\text { karena mal ini berada di dalam peta layanan PDAM } \\
\text { provinsi DKI Jakarta. }\end{array}$ \\
\hline 2 & $\begin{array}{l}\text { Adanya } \\
\text { penghematan } \\
\text { baru }\end{array}$ & air bersih \\
upaya & $\begin{array}{l}\text { Mal CITOS sepertinya belum menggunakan sistem daur } \\
\text { ulang air bekas untuk memenuhi kebutuhan pengguna } \\
\text { ataupun tanaman sekitar bangunan. }\end{array}$ \\
\hline
\end{tabular}

Sumber : Analisis pribadi, 2020

Dalam hal kualitas sumber air yang baik mal ini sudah memiliki kualitas sumber air yang baik, karena berada di dalam peta layanan PDAM setempat, kualitas air tanah yang ada juga terbilang sangat karena tidak berbau dan bersih. Dalam hal upaya penghematan air mal ini sepertinya belum menerapkan sistem daur ulang air bekas untuk digunakan kembali seperti menyiram tanaman dan flush pada toilet.

\section{Kesimpulan}

Penelitian ini merupakan kajian yang mengupas konsep arsitektur berkelanjutan dan penerapan nya pada studi kasus mal Cilandak Town Square. Peneliti menggunakan metode deskriptif kualitatif dalam penyusunan laporan ini, dimana dalam mengumpulkan data peneliti melakukan studi literatur dari sumber terkait sebagai 
pendukung dan melakukan observasi langsung ke lapangan untuk melengkapi data. Adapun didapatkan beberapa kesimpulan dari penelitan ini ialah :

a. Arsitektur berkelanjutan, merupakan salah satu contoh konsep penerapan arsitektur yang selain memperhatikan keberlangsungan hidup pengguna nya, juga memperhatikan alam dan lingkungan tempat bangunan tersebut berdiri.

b. Dalam kasus ini, terdapat perbedaan hasil penilaian dari masing - masing analisis dengan menggunakan parameter prinsip arsitektur berkelanjutan yang peneliti simpulkan. Adapun secara garis besar mal Cilandak Town Square sudah melakukan upaya dalam penerapan beberapa prinsip arsitektur berkelanjutan, akan tetapi perlu adanya peningkatan penerapan konsep arsitektur berkelanjutan guna menyelamatkan lingkungan dan memaksimalkan potensi yang ada pada mal Cilandak Town Square itu sendiri.

c. Prinsip arsitektur berkelanjutan, merupakan salah satu prinsip yang saat ini dibutuhkan oleh bumi kita saat ini, perlu adanya kesadaran bersama untuk lebih mewujudkan arsitektur yang berkelanjutan dan mengesampingkan ego untuk mengejar keuntungan semata. Sebenarnya arsitektur berkelanjutan dapat memberikan keuntungan jangka panjang bagi kita semua dan hal ini dapat dicapai tanpa menghilangkan esensi keindahan dan estetika sebuah bangunan. Itu semua merupakan tujuan demi pulihnya bumi dan lingkungan tempat kita bernanung saat ini.

\section{Referensi}

Aktas, A. P. (2012). Sustainable Design Proposals in Shopping Center Public Interior. International Journal of Energy and Environtment.

Anggana Fitri Satwikasari, L. H. (2018). Enchancing Thermal Environtmen Quality With Voids and As a Passive Design Strategy Towards Sustainable and Healty Living. Purwarupa.

Bauer, M., mosle, P., \& swarz, M. (n.d.). Green building, Guidebook For Sustainable Architecture. Stuttgart: Springer.

Chiara, J. D., \& callender, J. (1973). Time saver standards for building types 2nd edition. United States Of America: McGraw Hill International.

Gissen, D. (2003). Big and Green: Toward Sustainable Architecture in the 21 st Century. New York: Princeton Architectural Press .

Idedhyana, I. B. (2016). Perancangan Tapak Pada Mall Kuta Beachwalk Memadukan Alam Lingkungan dan Kearifan Lokal Menuju Arsitektur Berkelanjutan. Jurnal Teknik: Gradien.

Indonesia, G. B. (n.d.). Greenship rating tools. Retrieved from Green Building Council Indonesia: https://gbcindonesia.org/greenship/rating-tools

Lippsmier, G. (1994). Bangunan Tropis. Erlangga.

Mila, A. Y. (n.d.). Arsitektur berkelanjutan. 2005: Erlangga.

statistik, B. p. (2018). Profil pasar tradisional, pusat perbelanjaan, toko modern tahun 2018. Retrieved from Badan pusat statistik: https://www.bps.go.id/publication/2019/02/22/1fefad689bf331015b248efc/ profil-pasar-tradisional-pusat-perbelanjaan-dan-toko-modern-tahun-2018.html

Steele, J. B. (1997). Sustainable Architecture: Principles, Paradigms, and Case Studies . McGraw-Hill. 